\title{
Factors Explaining the Skills Transfer in Consulting Missions
}

\author{
Noura KSENTINI \\ Assistant Professor, Sfax University \\ Sfax - Tunisia \\ E-mail:nksentini@yahoo.fr
}

Karim MEZGHANI

Assistant Professor, Al Imam Mohammad Ibn Saud Islamic University (IMSIU)

Riyadh - Kingdom of Saudi Arabia

E-mail: mezghani_karim@yahoo.com

Received: Nov. 9, 2015

Accepted: Nov. 29, $2015 \quad$ Published: January 1, 2016

doi:10.5296/jmr.v8i1.8549

URL: http://dx.doi.org/10.5296/jmr.v8i1.8549

\begin{abstract}
The purpose of this article is to identify the factors that influence skills transfer from a consultant to a client during a consulting mission. A generic model is proposed in order to show the main factors in the context of an emerging country (Tunisia). Indeed, most works on this subject were performed in developed countries and involved the skills transfer in specific projects such as Enterprise Resources Planning (ERP) or research and development projects. This paper deals with three influencing factors that were addressed from previous works. Those factors are associated to: (1) the consultant, (2) the client and (3) the characteristics of skills to be transferred.

To test the proposed model, a questionnaire is developed and then addressed to projects managers in 31 Tunisian firms that have recourse to external consultants' services. The collected data are analyzed using Partial Least Squares (PLS) method.

The results of data analyses allow concluding that skills transfer is more influenced by factors related to the consultant (project management capabilities, communication competencies and industry experience) as well as the causal ambiguity of skills to be transferred.
\end{abstract}

Keywords: skills transfer, consultant, causal ambiguity. 


\section{Introduction}

Several previous researches have already shown that it is difficult for a company to own all the managerial skills, neither to have a specialized staff in all areas (Frederick and Buchot, 1984; Kubr, 1993; Stern and Tutoy, 1998; Villette, 2003). So, managers usually have recourse to external consultants to solve their managerial problems. Indeed, management consultants are considered as experts who have a set of knowledge and skills that can help managers to improve their business performance.

The emphasis on consulting business comes from the doctrine of "refocusing on the core business" (Villette, 2003). This doctrine encourages firms to involve external consultants for all kinds of work and expertise.

An external consultant helps to take a fresh look at familiar realities for members of the organization (Kubr, 1993; Stern and Tutoy, 1998). Indeed, it is theoretically admitted that consultants are able to make an objective and methodical analysis of the firm's situation. This analysis deals with experience and professional skills as well as independence of consultant from the firm's members. Havingre course to an external consultant can also be justified by the willingness to find a source of legitimacy in order to make accepted decisions and reduce some resistance from the firm's members (Boucher, 2004; Ksentiniand Mezghani, 2013).

Whatever the announced goal of the consultant intervention, the firm sees this intervention as an opportunity to develop new practices and new skills. In fact, the transfer of skills is seen as an important strategic tool for creating sustainable competitive advantage (Liao et al., 2011). However, such transfer is a difficult process to implement for several reasons: the skills cannot be considered as an object that can be easily transferred from one unit to another, the problem of information asymmetry, the lack of motivation, the lack of communication competencies, etc.

Difficulties in transferring skills would be stronger in the context of emerging countries such as Tunisia, where researches on this topic are scarce and the relationship consultant/client is characterized by "lack of value".

Given these problems, this paper aims to identify the main factors that encourage and/or facilitate the transfer of consultant expertise to the client company during a consulting mission. A literature review and a survey research through a sample of 31 Tunisian companies using management consultant services are conducted to identify these factors.

\section{Literature review}

\subsection{Skills and skills transfer: definition}

For a long time, the notion of skills remained frozen on a definition that describes it as a sum of knowledge and know-how which cannot be suitable now (Le Boterf, 2008).

Thus, a person is seen as skilled not only because he has the knowledge and know-how but by the fact that has the ability to implement the knowledge and know-how.

Defining a skilled person is difficult because the concept has several dimensions. Le Boterf 
(2000, 2002) adds that the skills cannot be defined without taking into account the context and the work situation. According to this author, skill has a collective dimension. This implies that acting competently is to know how to act with others, to analyze and explain his behavior. Collaboration and coordination capacities constitute the evidence of skills.

We can conclude from these definitions that the skill is the implementation of a coherent mix of resources (knowledge, know-how, abilities, experience,...) depending on the context and expected goals. This resource implementation is specific to each person and to his capacity for analysis and synthesis.

This multidimensional and evolving nature of skills concept makes transfer difficult.

Argote and Ingram (2000) define the transfer as the process by which a unit is affected by the experience of another unit. So, to successfully transfer skills, it is important to define and conceptualize skills while taking into account the context in which they will be transferred.

Presseau (2000) defines the transfer as the process by which knowledge built in a particular context is included in a new context, whether to build new knowledge or to perform new tasks.

To explain the skills transfer phenomenon, we adopt the perspective of Presseau and Frenay (2004) which moves away from the perspective that defines the transfer as a direct application of knowledge and skills in a new context and is closer to the perspective that emphasizes on reusing knowledge and skills to solve new problems. In this way, the transfer is also designed as a preparation for learning.

\subsection{Importance of skills transfer in consulting missions}

Companies cannot cover all the skills needed to carry out all organizational projects, especially those with innovative character (ISO certification, business reengineering, Enterprise Resources Planning (ERP), etc.). The consultant is expected to provide the necessary skills to help the client company to manage these projects (Hung et al., 2012). According to Lawrence and Lorsch (1989), the consultant has the necessary knowledge and expertise capacity to solve organizational problems. Poix (2002) argued that consultant is a "solutions provider" for the company.

Skills transfer is regarded as an important strategic tool for creating sustainable competitive advantage (Liao et al., 2011) and a key factor in the company's performance maximization (Prévot, 2002). In reference to the Resource-Based View (Wernerfelt, 1984; Barney, 1991; Grant, 1991; Prahalad and Hamel, 1990), the source of competitive advantage for a firm lies in its capacity to hold key skills. These skills are attributed to the mobilization of a specific portfolio of resources that an organization owns. To ensure a sustainable competitive advantage, the manager should renew and develop the skills portfolio. Indeed, when facing environmental changes, firms need to distinguish themselves from others through their stock of dynamic skills.

In this sense, transfer of skills from a consultant to the client can be considered as a tool which allows the company to acquire new resources and skills. Moreover, leaders should 
inculcate a culture that encourages and promotes the skills transfer from consultants to the company's members. The transfer will thus increase the performance of the organization by a transmission and a "mutation" of these skills (Ciobanu et al., 2009).

\section{Research model and hypotheses}

Based on previous works, this section presents factors that could influence skills transfer. These factors are linked to the consultant, the client and the skills to be transferred.

\subsection{Factors linked to the consultant}

According to the literature, there are a number of factors that can facilitate the transfer of skills related to the consultant. These factors are: project management capabilities, communication competencies and industry experience.

\subsubsection{Project management capabilities}

Project management capabilities can be defined as the ability to plan, organize, direct and control the project resources to achieve its implementation (Somers and Nelson, 2004; Singla and Goyal, 2007).

Somers and Nelson (2004) pointed that project management capabilities refer to the ability to keep a schedule for the project to avoid time and cost overruns.

According to Hung et al. (2012), consultant's project management capabilities help to create a suitable atmosphere for the knowledge transfer. In fact, by its ability to properly plan and manage the steps and schedule of a project, the consultant could maintain a favorable environment within the project team to facilitate the transfer. Hence the following hypothesis:

H1: The consultants' project management capabilities facilitate the skills transfer.

\subsubsection{Communication competencies}

The communication competencies can be defined as the ability to clearly define and explain ideas and facts in written or oral form, the ability to perceive and respond to the others' needs, the ability to listen to others and the ability to persuade them to change their ideas or behaviors (Jackson, 1996; Mumford et al., 2007; Mezghani and Mezghani, 2014).

Skills transfer involves continuous communication that requires communication competencies from the consultant (the source of skills) to easily disseminate these skills (Xu and Ma, 2008). Moreover, the consultant is known for its persuasive speech that helps convince managers and spread its ideas (Guillaume, 2009). Thus, it is possible to state the following hypothesis:

H2: The consultant's communication competencies facilitate the skills transfer.

\subsubsection{Industry experience}

According to McLachlin (1999) and Kumar et al. (2002), industry experience refers to the consultant's previous similar experience and familiarity with the problem the firm faces. 
Lee et al. (2006) pointed out that the experience of a consultant in the field has a significant influence on the success of knowledge transfer. If the consultant has relevant experience, he could more easily understand how the firm operates. Hung et al. (2012) showed in their study that if the client perceives the consultant as experienced in the project field, its willingness to get new skills would increase. In a knowledge sharing context, Park et al. (2015) add that "the perceived expertise of the partner can also increase the partner's trust in the customer" so sharing is facilitated.

Hence the following hypothesis:

H3: The consultant's industry experience has a positiveeffect on the skills transfer.

\subsection{Factors linked to the client}

These factors are linked to communication competencies, top management support, acquisition willingness and the shared domain knowledge.

\subsubsection{Communication competencies}

As for the consultant, the client (skills receiver) needs communication competencies to assimilate new knowledge and skills (Xu and Ma, 2008; Strasser and Westner, 2015). In fact, these competencies contribute to improve the absorption capacity of the client. Besides, communication skills help the client to better define its needs in a consulting mission, allowing the consultant to better focus its efforts and identify the skills to be transferred (Xu and $\mathrm{Ma}, 2008)$. Therefore, we propose the hypothesis H4 as follows:

H4: The client's communication competencies facilitate the skills transfer.

\subsubsection{Top management support}

Wang et al. (2006) define the top management support as the resources and authority provided by the top management to guide and assist the project achievement.

Previous researches reveal how managerial attitudes may affect the acceptance of new systems by end users (Eisenhardt, 1985; Karlsen, 2004; Li and Lin, 2006; Wang et al., 2006; Tsai et al., 2011). McLachlin (1999) pointed out that, to promote the adoption of a new system within an organization, top management should understand the linked project, initiate the new system implementation and explain the managerial implications to employees.

The top management support helps maintain a suitable environment for knowledge transfer (Hung et al., 2012; Arnett and Wittmann, 2014). Indeed, external intervention (from a consultant) involves structural changes. Therefore, the support from the top management could limit the internal resistance and motivate the company's members involved in the project to acquire new skills. Hence we formulate the following hypothesis:

H5: The top management support facilitates the skills transfer.

\subsubsection{Acquisition willingness}

If not motivated, the employees involved in an organizational project with a consultant may 
reject new knowledge. Practitioners typically consider internal problems, lack of incentives and lack of confidence as barriers to knowledge transfer (Xu and Ma, 2008; Strasser and Westner, 2015). Thus, despite the top management support, the client (receiver) could find that interaction with a consultant in the project is unnecessary. In this case, he will not be motivated to build and maintain knowledge or skills transfer climate (Hung et al., 2012).

Thus, it is possible to formulate the following hypothesis:

H6: The acquisition willingness has a positive effect on the skills transfer.

\subsubsection{Shared domain knowledge}

Such as for the consultant considered as "expert", the receiver would necessitate a certain level of knowledge for the project accomplishment. According to Szulanski (2000), experience on the project-linked domain is a factor that positively influences the knowledge transfer. Indeed, in reference to the knowledge-based view, shared domain knowledge can facilitate sharing of knowledge that is not common (Grant, 1996).

The common knowledge help to create "absorptive capacity" required to receive new knowledge, enabling individuals to integrate aspects of knowledge that are not common to them (Kearns and Sabherwal, 2007). Indeed, when a specialist wants to diffuse new knowledge or practices, the recipient would requires a certain level of mutual(shared) knowledge with the sender to understand and assimilate this new knowledge (Kearns and Sabherwal, 2007).

We formulate thus, hypothesis $\mathrm{H} 7$ as follows:

H7: The shared domain knowledge has a positive effect on the skills transfer.

\subsection{Factors linked to the skills to be transferred}

These factors are linked to the skills transferability (type and characteristics of skills to be transferred). By reference to Xu and Ma (2008), knowledge to be transferred can be:

- Tacit: resulting from learning by doing (Reed and Defillippi, 1990). Tacitness has a negative effect on the knowledge transfer (Cummings and Teng, 2003).

- Characterized by causal ambiguity: concerns the difficulty to understand logical linkages between actions and outcomes, inputs and outputs, causes and effects. Szulanski (1996) showed, when studying the transfer of managerial practices in organizations, that causal ambiguity is seen as an obstacle and has a negative effect on the knowledge transfer.

In reference to the resource-based view, the resource tacitness reinforces its causal ambiguity (Reed and Defillippi, 1990). According to Uygur (2013), "If knowledge is tacitly stored in the individual or the collective mind, then the causal relationships among particular actions and their results are less likely to be identified". So, causal ambiguity plays a mediating role between tacitness and transfer (Reed and Defillippi, 1990).

Therefore, we can consider that it is mainly the causal ambiguity which would have a direct effect on the skills transfer (Bénédic and Bayad, 2008; Uygur, 2013). So, according to 


\section{Macrothink}

previous studies, we formulate the following hypothesis:

H8: The causal ambiguity has a negative effect on the skills transfer.

Based on this theoretical analysis, we propose our research model (Figure 1) which presents the factors that could influence the skills transfer.

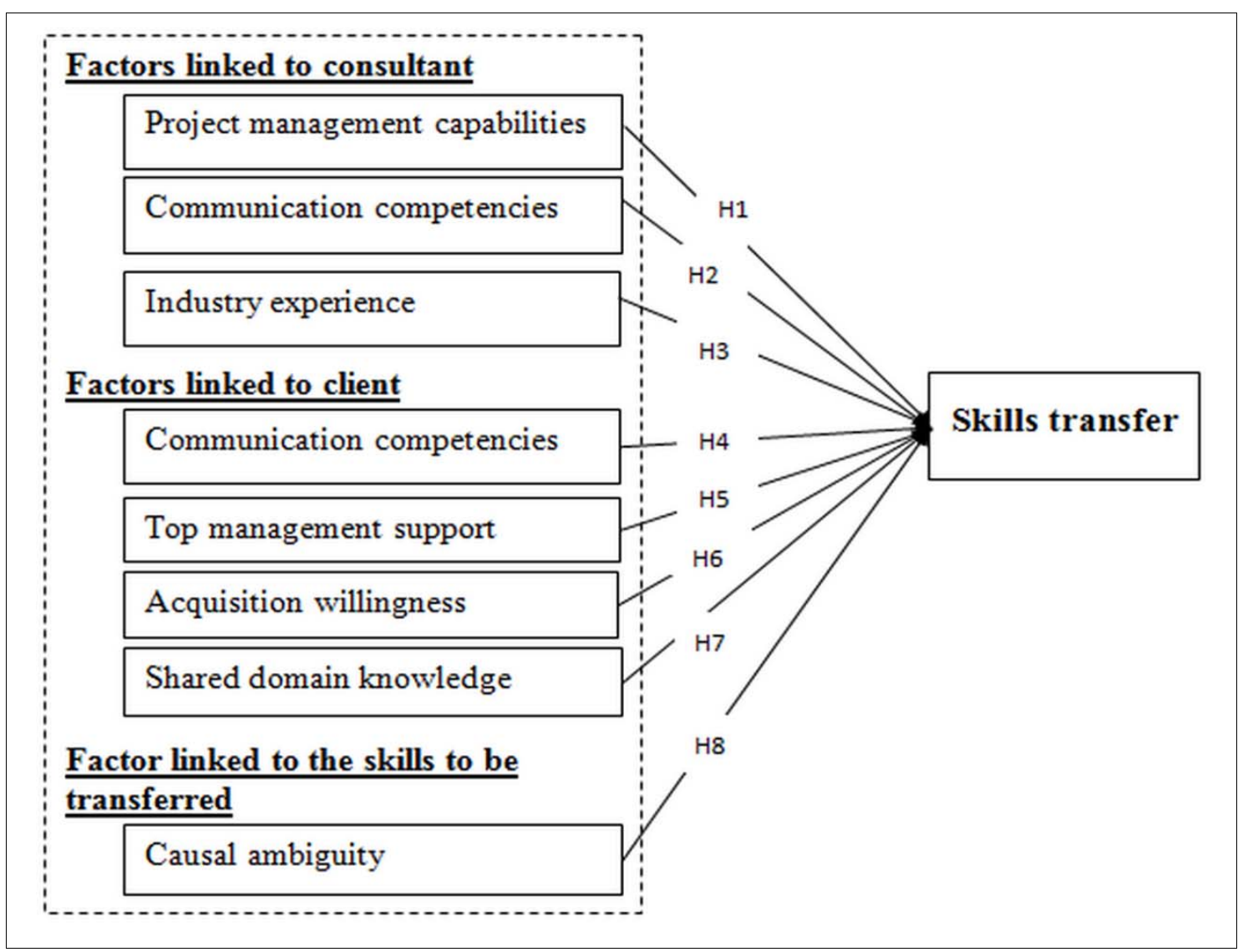

Figure 1. The research model

\section{Research methodology}

To test the research hypotheses, a questionnaire was built based on the variables measures identified and adapted from previous works (table 1). 
Table1. The variables measures

\begin{tabular}{|c|c|c|c|c|}
\hline Factors & Variables & Definitions & Measures (adapted) & Authors \\
\hline \multirow[t]{2}{*}{ Consultant } & $\begin{array}{l}\text { Project } \\
\text { management } \\
\text { capabilities } \\
\text { (Consprojet) }\end{array}$ & $\begin{array}{l}\text { The ability to plan, } \\
\text { organize, direct } \\
\text { and control the } \\
\text { project resources } \\
\text { to achieve its } \\
\text { implementation. }\end{array}$ & $\begin{array}{l}\text { - The consultant lacks } \\
\text { appropriate project } \\
\text { schedules, plans and a clear } \\
\text { strategy for implementation. } \\
\text { - Each stage of the project was } \\
\text { completed on time. } \\
\text { - Each stage of the project was } \\
\text { completed within budget. } \\
\text { - The project achieved } \\
\text { expected performance and } \\
\text { quality standards. } \\
\text { - Project manager was able to } \\
\text { re-coordinate the schedule } \\
\text { when schedules were not } \\
\text { met. } \\
\text { Project members stayed } \\
\text { engaged with their work until } \\
\text { project completion. }\end{array}$ & $\begin{array}{l}\text { Somers } \\
\text { and } \\
\text { Nelson } \\
\text { (2004), } \\
\text { Singla and } \\
\text { Goyal } \\
\text { (2007), } \\
\text { Hung et } \\
\text { al. (2012) }\end{array}$ \\
\hline & $\begin{array}{l}\text { Communication } \\
\text { competencies } \\
\text { (Conscomm) }\end{array}$ & $\begin{array}{l}\text { The ability to } \\
\text { clearly define and } \\
\text { explain ideas and } \\
\text { facts in written or } \\
\text { oral form, the } \\
\text { ability to perceive } \\
\text { and respond to the } \\
\text { others' needs, the } \\
\text { ability to listen to } \\
\text { others and the } \\
\text { ability to persuade } \\
\text { them to change } \\
\text { their ideas or }\end{array}$ & $\begin{array}{l}\text { - The ability to clearly define } \\
\text { and explain ideas and facts in } \\
\text { written or oral form. } \\
\text { - The ability to perceive and } \\
\text { respond to the others' needs. } \\
\text { - The ability to listen to others. } \\
\text { - The ability to persuade them } \\
\text { to change their ideas or } \\
\text { behaviors. }\end{array}$ & $\begin{array}{l}\text { Jackson } \\
(1996) \text {, } \\
\text { Mumford } \\
\text { et al. } \\
\text { (2007), } \\
\text { Mezghani } \\
\text { and } \\
\text { Mezghani } \\
\text { (2014) }\end{array}$ \\
\hline
\end{tabular}




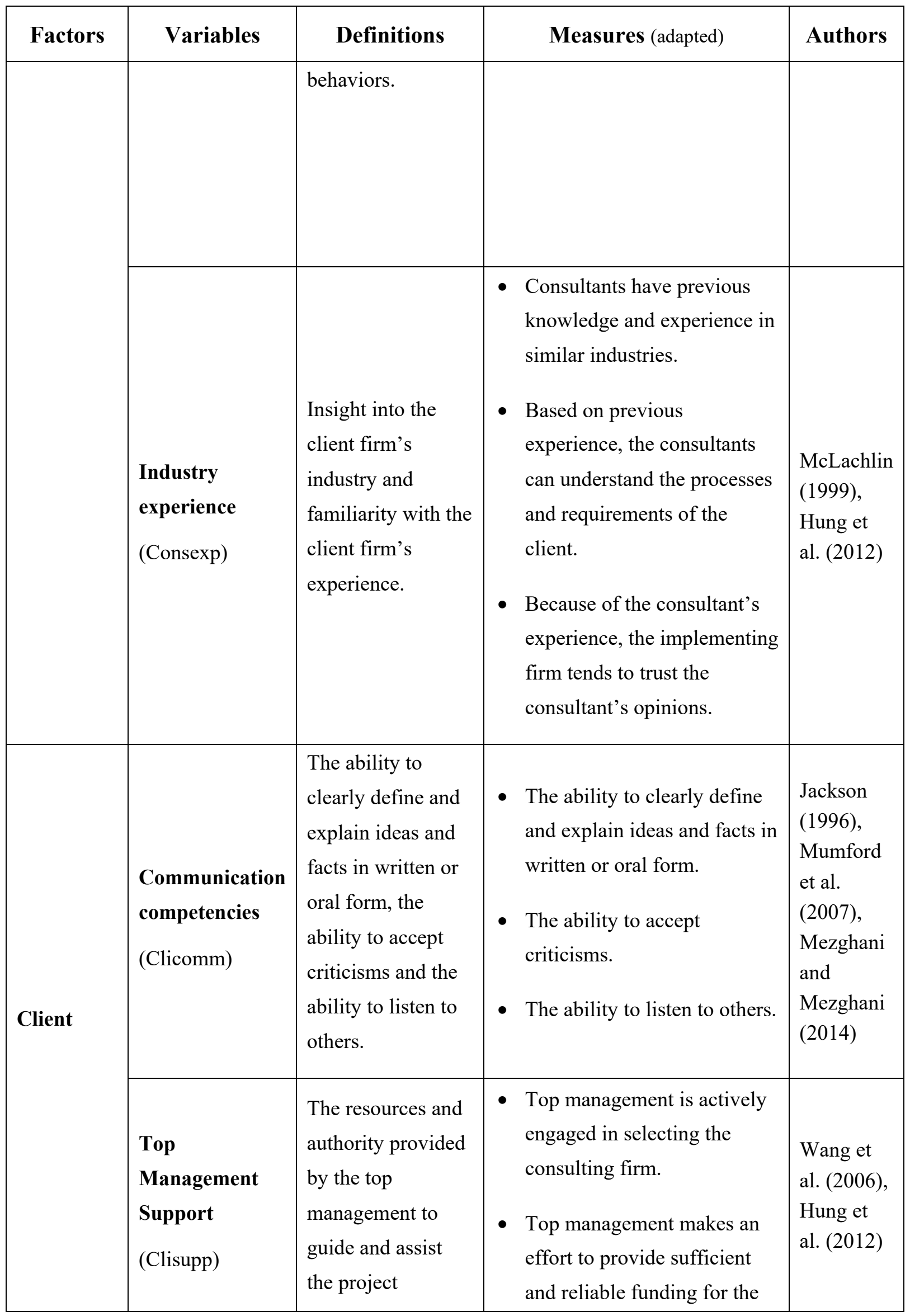




\begin{tabular}{|c|c|c|c|c|}
\hline Factors & Variables & Definitions & Measures (adapted) & Authors \\
\hline & & achievement. & $\begin{array}{l}\text { project. } \\
\text { - Top management is actively } \\
\text { engaged in recruiting the } \\
\text { personnel needed for the } \\
\text { project. } \\
\text { - Top management is very } \\
\text { concerned with the } \\
\text { performance of the project. }\end{array}$ & \\
\hline & $\begin{array}{l}\text { Acquisition } \\
\text { willingness } \\
\text { (Clivol) }\end{array}$ & $\begin{array}{l}\text { The degree to learn } \\
\text { knowledge/skills. }\end{array}$ & $\begin{array}{l}\text { - I value the opportunity to take } \\
\text { part in this project. } \\
\text { - I want to pay more attention } \\
\text { and time to learn new } \\
\text { knowledge during the project. } \\
\text { - I enjoy learning knowledge } \\
\text { that is completely new to me. }\end{array}$ & $\begin{array}{l}\mathrm{Xu} \text { and } \\
\mathrm{Ma}(2008)\end{array}$ \\
\hline & $\begin{array}{l}\text { Shared domain } \\
\text { knowledge } \\
\text { (Cliconnai) }\end{array}$ & $\begin{array}{l}\text { Common } \\
\text { knowledge on the } \\
\text { project topic. }\end{array}$ & $\begin{array}{l}\text { I am knowledgeable about } \\
\text { the project topic before } \\
\text { participating in the current } \\
\text { mission. } \\
\text { - I already participated in } \\
\text { similar projects. } \\
\text { - I performed searches on the } \\
\text { project topic. }\end{array}$ & $\begin{array}{l}\text { Kearns } \\
\text { and } \\
\text { Sabherwal } \\
\text { (2007), } \\
\text { Mezghani } \\
\text { and } \\
\text { Mezghani } \\
\text { (2014) }\end{array}$ \\
\hline
\end{tabular}




\begin{tabular}{|c|c|c|c|c|}
\hline Factors & Variables & Definitions & Measures (adapted) & Authors \\
\hline Skills & $\begin{array}{l}\text { Causal } \\
\text { ambiguity } \\
\text { (Competence) }\end{array}$ & $\begin{array}{l}\text { Lack } \\
\text { understanding of } \\
\text { the logical linkages } \\
\text { between actions } \\
\text { and outcomes, } \\
\text { inputs and outputs, } \\
\text { and causes and } \\
\text { effects that are } \\
\text { related to } \\
\text { technological or } \\
\text { process know-how. }\end{array}$ & $\begin{array}{l}\text { - There is a precise list of the } \\
\text { skills, resources and } \\
\text { prerequisites necessary for } \\
\text { the project success. } \\
\text { - It is well known how the } \\
\text { components of that list } \\
\text { interact to produce the } \\
\text { expected outputs. } \\
\text { The association between } \\
\text { causes and effects, inputs and } \\
\text { outputs, and actions and } \\
\text { outcomes related to the } \\
\text { project is clear. } \\
\text { Existing work manuals and } \\
\text { operating procedures } \\
\text { describe precisely what } \\
\text { people working in the project. } \\
\text { could not be articulated. }\end{array}$ & $\begin{array}{l}\text { Szulanski } \\
(1996), \mathrm{Xu} \\
\text { and } \mathrm{Ma} \\
(2008)\end{array}$ \\
\hline & $\begin{array}{l}\text { Skills transfer } \\
\text { (Transfert) }\end{array}$ & $\begin{array}{l}\text { The } \\
\text { communication of } \\
\text { knowledge and } \\
\text { skills from a } \\
\text { source (consultant) } \\
\text { so that they are } \\
\text { learned and } \\
\text { applied by a } \\
\text { recipient (client). }\end{array}$ & $\begin{array}{l}\text { During the project, my } \\
\text { interactions with the } \\
\text { consultant improved my } \\
\text { knowledge/skills. } \\
\text { - I have used these skills in } \\
\text { other projects. } \\
\text { - I reduced my dependence on } \\
\text { the consultant. }\end{array}$ & $\begin{array}{l}\text { Simonin } \\
\text { (1999), } \\
\text { Presseau } \\
\text { and } \\
\text { Frenay } \\
\text { (2004), Ko } \\
\text { et al. } \\
\text { (2005) }\end{array}$ \\
\hline
\end{tabular}


After pre-testing it, the questionnaire was administered to managers, within Tunisian firms, who have managed organizational projectsthat involved external consultants' participation. We note that it was difficult to draw up a list of such firms since the relationship with external consultants is often regarded as confidential.

Only 31 firms have agreed to complete the questionnaire, despite multiple contacts by phone, directly or via email. Regarding the achieved sample size, we opted for the XLSTAT software as a tool for analyzing the collected data. In addition to its ability to perform factor analyses, this software allows to perform structural equation modeling (SEM) analyses with PLS technique to test causal links. According to Fernandes (2012), PLS technique is suitable fora small sample size $(100 \geq \mathrm{n} \geq 30)$.

"One of the advantages of PLS is the ability to assess model fit using a unique fit index" (Mezghani and Ayadi, 2016). Indeed, "there is no overall fit index in PLS Path Modeling. Nevertheless, a global criterion of goodness of fit has been proposed by Tenenhauset al. (2004): the GoF index. Such an index has been developed in order to take into account the model performance in both the measurement and the structural model and thus provide a single measure for the overall prediction performance of the model" (Vinziet al., 2010).

\section{Results}

\subsection{Results of descriptive analyses}

To check the intrinsic characteristics of latent variables, we conducted factor analyses. These analyses allowed us to purify the variables measures and verify the factor structure of each variable.

These results were then verified thanks to reliability and validity tests conducted by the PLS method. Indeed, the Cronbach's alpha, Dillon-Goldstein rho and average variance extracted (AVE) results confirmed the reliability and the validity of the variables measures (Table 2 ).

Table 2 . The results of reliability and validity tests

\begin{tabular}{|l|c|c|c|}
\hline Latent Variables & $\begin{array}{c}\text { Cronbach's } \\
\text { Alpha }(>\mathbf{0 . 7})\end{array}$ & $\begin{array}{c}\text { D.GRho } \\
\mathbf{( > 0 . 8 )}\end{array}$ & $\begin{array}{c}\text { AVE } \\
(>\mathbf{0 . 5})\end{array}$ \\
\hline Consprojet & 0.820 & 0.874 & 0.558 \\
\hline Conscomm & 0.872 & 0.913 & 0.724 \\
\hline Consexp & 0.764 & 0.865 & 0.679 \\
\hline Clisupp & 0.872 & 0.913 & 0.719 \\
\hline Cliconnai & 0.707 & 0.872 & 0.766 \\
\hline Clivol & 0.773 & 0.869 & 0.587 \\
\hline Clicomm & 0.841 & 0.926 & 0.860 \\
\hline Competence & 0.740 & 0.852 & 0.645 \\
\hline Transfert & 0.775 & 0.899 & 0.815 \\
\hline
\end{tabular}




\section{Macrothink}

\subsection{Results of explanatory analyses}

\subsubsection{Model fit}

Within the PLS approach, a single global index of goodness of fit can be used. This is the GoFindex (Goodness-of-Fit) developed by Tenenhaus et al. (2004).

At the beginning, the values of GoF and the $\mathrm{R}^{2}$ of the variable "Transfer" were low. So we eliminated the variable "Clivol" (Acquisition willingness)whose effect was notsignificant. The obtained GOF values after a second model estimation are shown in the following table:

Table 3. Goodness of fit

\begin{tabular}{|l|l|}
\hline & GoF \\
\hline Absolute & 0.595 \\
\hline Relative & 0.699 \\
\hline External Model & 0.978 \\
\hline Internal Model & 0.715 \\
\hline
\end{tabular}

The absolute GoF is used to compare several models (Stan and Saporta, 2006). So, it is not useful for this research. The other GoF values are high and reflect a good model fit (internal and external). Then, it is possible to proceed to the hypotheses test.

\subsubsection{Hypotheses Test}

To verify the research hypotheses, we analyzed the statistical results linked to the structural model presented as follows:

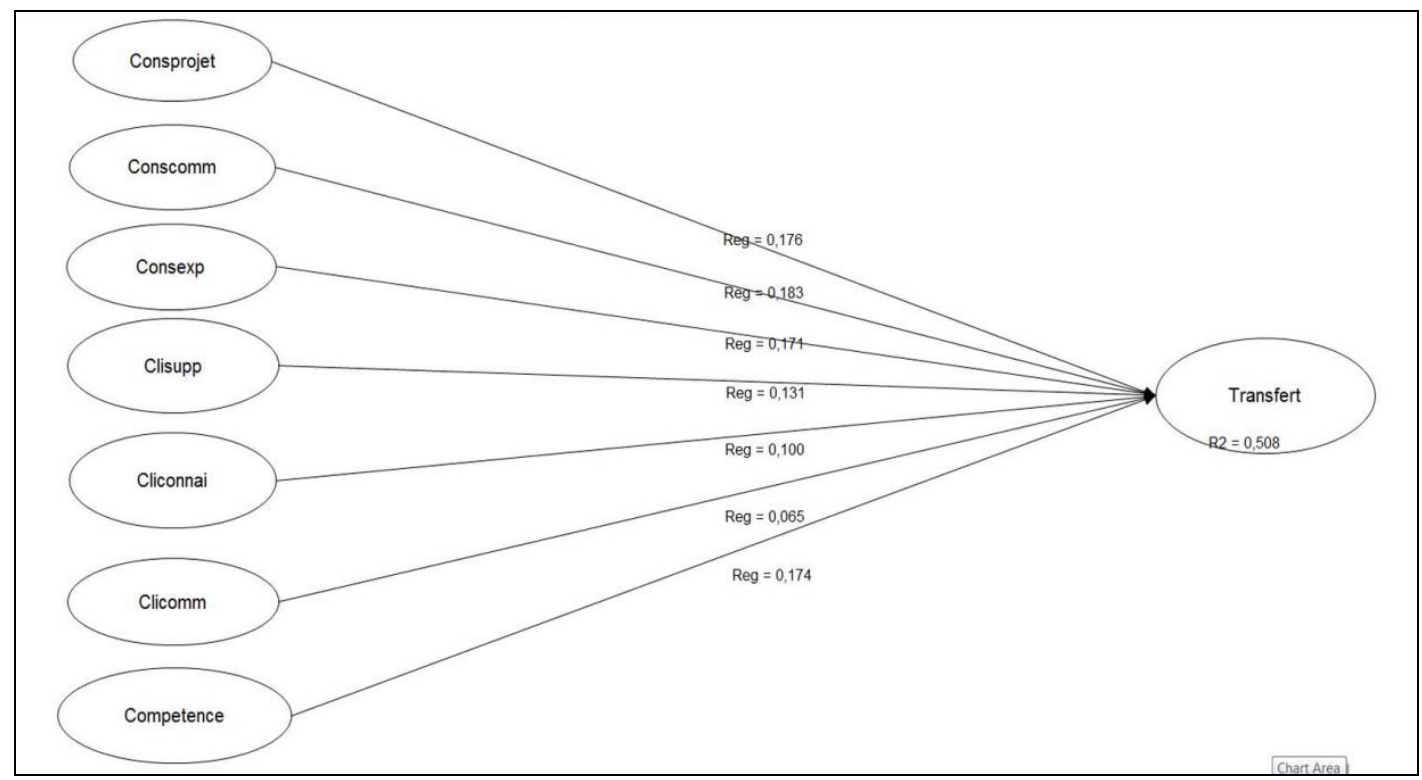

Figure 2. The fitted structural model 


\section{Macrothink}

The value of $\mathrm{R}^{2}$ of the variable "Transfer" is high (0.508) which means that this variable is strongly influenced by the independent variables identified in this research. This can be verified when analyzing the critical ratio (CR) of regression links between the independent variables and the "Transfer" variable (Table 4).A CR value greater than 1.96 shows that the regression link is significant.

Table 4. Significance of regression links

\begin{tabular}{|l|l|c|c|}
\cline { 2 - 4 } \multicolumn{1}{c|}{ Latent Variables } & $\begin{array}{c}\text { Regression } \\
\text { links value }\end{array}$ & $\begin{array}{c}\text { Critical Ratio } \\
\text { (CR) (>1.96) }\end{array}$ \\
\hline \multirow{4}{*}{ Consultant } & Project management capabilities & 0.176 & $\mathbf{2 . 8 0 3}$ \\
\cline { 2 - 5 } & Communication competencies & 0.183 & $\mathbf{5 . 2 7 4}$ \\
\cline { 2 - 4 } & Industry experience & 0.171 & $\mathbf{3 . 3 7 2}$ \\
\hline \multirow{3}{*}{ Client } & Top management support & 0.131 & $\mathbf{2 . 7 5 1}$ \\
\cline { 2 - 5 } & Shared domain knowledge & 0.100 & 1.608 \\
\cline { 2 - 4 } & Communication competencies & 0.065 & 1.054 \\
\hline & Causal ambiguity & $0.174^{*}$ & $\mathbf{2 . 7 0 5}$ \\
\hline
\end{tabular}

* The items measuring the characteristics of skills (causal ambiguity) were reversed. The positive value of the regression indicates therefore that the hypothesis 8 is verified.

From these results, it is possible to find that the skills transfer is more influenced by variables related to the consultant and the causal ambiguity of the skills to be transferred. In the client side, statistical tests show that only the variable "top management support" has a significant effect on the transfer. The results of the hypotheses test are summarized in Table 5: 
Table 5. Results of hypotheses test

\begin{tabular}{|l|c|}
\hline \multicolumn{1}{|c|}{ Hypotheses } & Results \\
\hline $\begin{array}{l}\text { H1:The consultants' project management capabilities facilitatethe skills } \\
\text { transfer }\end{array}$ & Supported \\
\hline $\begin{array}{l}\text { H2:The consultant's communication competencies facilitate the skills } \\
\text { transfer }\end{array}$ & Supported \\
\hline $\begin{array}{l}\text { H3:The consultant's industry experience has a positive effect on the skills } \\
\text { transfer }\end{array}$ & Supported \\
\hline H4:The client's communication competencies facilitate skills transfer & $\begin{array}{c}\text { Not } \\
\text { Supported }\end{array}$ \\
\hline H5:The top management support facilitates the skills transfer & Supported \\
\hline H6:The acquisition willingness has a positive effect on the skills transfer & $\begin{array}{c}\text { Not } \\
\text { Supported }\end{array}$ \\
\hline H7:The shared domain knowledge has a positive effect on the skills transfer & $\begin{array}{c}\text { Not } \\
\text { Supported }\end{array}$ \\
\hline H8:The causal ambiguity has a negative effect on the skills transfer & Supported \\
\hline
\end{tabular}

\section{Discussion}

\subsection{The consultant as a key element for the skills transfer}

As shown in literature review, the consultant-linked factors are all considered as key factors for successful skill stransfer. This result is not surprising; especially since the responses are collected from "client" (the questionnaire was sent to companies' members that have interacted with a management consultant when accomplishing an organizational project).In fact, if a company involves external consultants in an organizational project, this means that it considers them as key elements that have the required experience and skills to successfully achieve the project.

Moreover, the consultant is considered as an expert and that is why he is requested. According to Ksentini and Mezghani (2013), the consultant is seen by the customers as a diffuser of managerial techniques bringing solutions to organizational problems. In this way, Hung et al. (2012) state that the more the customer perceives the consultant as an expert, the more he will tend to learn from him. Thus, in an ERP project for example, involving a consultant whose curriculum vitae has no past experience with ERP, would not be attractive to the client company that seeks to acquire specific skills to carry out such project.

However, having skills is not sufficient to be able to transfer them. This is clear from the regression links values showing that project management capabilities and communication competencies have more important effects on the transfer. Hung et al. (2012) argue that the "project management capabilities" is the most influential factor on the transfer success. In fact, an experienced consultant in project management would help participants to define their 
needs more clearly and to identify the necessary skills to be transferred: "An experienced external consulting and support team can help the project team to define the project scope more accurately and properly deal with different user requests"(Hung et al., 2012).

In terms of "communication competencies", the importance of this factor in the transfer is noted, in previous studies, both from the consultant side and the client one (Xu and $\mathrm{Ma}$, 2008). According to these authors, communication is needed to skills transfer. Thus, the source of these skills (the consultant) must be able to express itself clearly. In fact, it is difficult to make a transfer if the consultant cannot express his ideas or if he uses a technical vocabulary that is not understandable by the client.

In this research, the consultant's communication competencies involve also the ability to listen and understand the clients' needs which are relevant for the skills transfer. This means that even before transmitting his skills, the consultant must be able to decode the information collected from the client to better analyze the situation and identify the skills to be transferred.

Thus, while most previous research, like $\mathrm{Xu}$ and Ma (2008), consider consultant's communication competencies as needed for encoding, the results of this research show that the consultant needs to decode and then encode to be able to foster the transfer.

\subsection{The role of the client in the skills transfer}

The statistical results show that, among the factors related to the client, only top management support influences the skills transfer. Several previous studies, like Hung et al. (2012), insist on this support as a key factor for the success of a consulting mission, particularly with regard to the transfer. In fact, Ksentini and Mezghani (2013), argue that the presence of a consultant in a company may be accompanied by a resistance from employees who consider this presence as the start of an organizational change. To reduce this resistance, the top management involvement will be necessary to encourage employees to work with the consultant and create a suitable transfer climate (Hung et al., 2012).

Regarding the other factors related to client, the lack of significance through the links with the transfer can be explained by the fact that the results are based on the clients' responses (receivers of skills).

First of all, some factors are related to client capabilities (communication capabilities, shared domain knowledge, etc.). The concerned person would find it difficult to objectively evaluate its abilities because of the egocentric bias related to self-assessment. Also, respondents would believe that the responsibility of skills transfer is linked to the consultant as an "expert" supposed to bring solutions. Moreover, according to Hung et al.(2012), a successful skills transfer remains relying on factors related rather to the consultant, as holder of these skills.

\subsection{The transfer depends on skills to be transferred}

In this research, which does not deal with specific skills, it is considered that the nature of skills to be transferred can influence transfer. Moreover, according to Uygur (2013), the successful transfer is largely dependent on the characteristics of knowledge or skills to be 
transferred. Indeed, in reference to the resource based view, skills cannot be easilydiffused if they remain implicit or characterized by causal ambiguity.

Unlike previous works claiming that skills transfer is dependent only on the source (consultant) and receiver (client), it was verified in this research that the characteristics of skills to be transferred significantly influence the transfer. In fact, it is not sufficient that the consultant and the client have the necessary capabilities to transfer if the skills are not easily transferable.

In this way, the results of statistical tests conducted by Xu and Ma (2008) and Hung et al. (2012) stipulate that the transfer of skills is facilitated by the existence of a suitable climate for the transfer. This climate is built by both parties (consultant and client). In addition to the climate, $\mathrm{Xu}$ and $\mathrm{Ma}$ (2008) emphasize on the role of causal ambiguity as an obstacle to the successful transfer despite the existence of a suitable climate.

When analyzing the items adopted to measure causal ambiguity, it appears that if the client has not a prior idea of the skills needed to conduct the project and especially on how to articulate these skills to produce the expected outputs, he would find it difficult to assimilate or re-use them subsequently without having recourse to the help of a consultant.

\section{Conclusion}

This research aimed to identify factors explaining the skills transfer during a consulting mission. In fact, searching for key skills is one of the main reasons why companies have recourse to the services of a consultant. However, the skills transfer is a true challenge since it depends on several multidimensional factors (Xu and Ma, 2008; Hung et al, 2012.).

Through a literature review focusing on the transfer concept, a research model presenting factors that may influence the transfer was developed. This model was then tested via a questionnaire survey through a sample of Tunisian firms that usually have recourse to the external consultants services.

The statistical tests performed with the PLS technique highlights two main results:

- The skills transfer is influenced by factors related to the consultant (source of skills), the client (receiver of skills) and the skills to be transferred (causal ambiguity).

- The transfer is influenced mainly by factors related to the consultant. In addition to his responsibility as an expert who assists the company in complex projects, the consultant is considered as the main source of the transfer success or failure.

In addition to these two results, this research allowed us to propose a generic research model (Figure 1)as a theoretical contribution given that most previous research has focused on the transfer in specific projects. This model may be useful for practitioners also by helping them to know and understand several factors that facilitate skills transfer.

Beyond these results, some research limitations must be noted. In fact, the responses were collected only from the client side. Extending the survey to the consultants would be necessary to know the "other" perspective and improve the results. 
Another limitation is the small sample size which led the authors to use the PLS method. This method, although adequate for small samples, remains suitable for prediction rather than confirmation. Using other methods, like LISREL, in future researches could help to confirm the obtained results. This involves the need to collect a higher number of responses.

\section{References}

Argote, L. \& Ingram, P. (2000). Knowledge transfer: a basis for competitive advantage in firms. Organizational behavior and human decision processes, 8(2), 150-169. http://dx.doi.org/10.1006/obhd.2000.2893

Arnett, D. B., \&Wittmann, C. M. (2014). Improving marketing success: The role of tacit knowledge exchange between sales and marketing.Journal of Business Research, 67(3), 324-331. http://dx.doi.org/10.1016/j.jbusres.2013.01.018

Barney, J. (1991). Firm resources and sustained competitive advantage. Journal of management, 17(1), 99-120. http://dx.doi.org/10.1177/014920639101700108

Bénédic, M. \&Bayad, M. (2008). Etude des facteurs de succès du processus de transfert de connaissances au sein des réseaux d'innovation: proposition d'un cadre conceptuel.Conference "En route vers Lisbonne", 4-5 décembre.

Boucher, E. P. (2004). Les fonctions symboliques des consultants: Le cas des multinationales $\mathrm{du}$ conseil.Proceedings of the $11^{\text {th }}$ Conference of AIMS, Normandie, Vallée de Seine (France).

Buchot, T. \&Fréderic,P. (1984). Pourquoi un consultant est-il appelé à intervenir dans une entreprise ? Futuribles, (81), 49-55.

Centre du Commerce International (CCI) (2011). Stratégie de développement des exportations tunisiennes des Services Conseils aux Entreprises.http://www.intracen.org/Workarea/DownloadAsset.aspx?id=76148.

Ciobanu, R. Chaumon B. R. \& Grosjean, M. (2009). Les conditions du transfert de compétences dans un contexte interculturel : le cas d'une entreprise spécialisée dans les services aux entreprises. Les Carnets du GRePS, (1), 51-60.

Cummings, J. L., \&Teng, B. S. (2003). Transferring R\&D knowledge: the key factors affecting knowledge transfer success. Journal of Engineering and technology management, 20(1), 39-68. http://dx.doi.org/10.1016/S0923-4748(03)00004-3

Eisenhardt, K. M. (1985). Control: Organizational and economic approaches. Management science, 31(2), 134-149. http://dx.doi.org/10.1287/mnsc.31.2.134

Fernandes, V. (2012). (Re) discovering the PLS approach in management science. M@n@gement,15(1),101-123.

Grant, R. M. (1996). Toward a knowledge-based theory of the firm.Strategic management journal, 17(S2), 109-122. http://dx.doi.org/10.1002/smj.4250171110 
Guillaume, O. (2009).Les dispositifs de gestion: des modes managériales imposées. Sociologie de la Gestion, (3), 1-4.

Hung, W. H., Ho, C. F., Jou, J. J., \& Kung, K. H. (2012). Relationship bonding for a better knowledge transfer climate: An ERP implementation research. Decision Support Systems, 52(2), 406-414. http://dx.doi.org/10.1016/j.dss.2011.09.007

Jackson, T. R. (1996).Effects of organizational structure on new housing professionals' development of effective mid-level administrative skills.Published doctoral Dissertation (La Verne University-California).

Karlsen, J. T., \& Gottschalk,P. (2004). Factors affecting knowledge transfer in IT projects.Engineering Management Journal, 30-38. http://dx.doi.org/10.1080/10429247.2004.11415233

Kearns, G., \&Sabherwal, R. (2007). Strategic Alignment Between Business and Information Technology: A Knowledge-Based View of Behaviors, Outcome, and Consequences. Journal of Management Information Systems, 23(3), 129-162. http://dx.doi.org/10.2753/MIS0742-1222230306

Ko, D. G., Kirsch, L. J., \& King, W. R. (2005). Antecedents of knowledge transfer from consultants to clients in enterprise system implementations. MIS Quarterly,29(1), 59-85.

Ksentini, N. \&Mezghani,K. (2013). Factors affecting diffusion of management fashions during consulting missions: An exploratory study in Tunisian context. International Journal of Independent Research and Studies, 2(4), 156-164.

Ksentini, N. (2009). Le conseil en management en Tunisie: caractéristiques du marché, fonctionnement des cabinets et effet de mode.Doctoral Dissertation(Sfax University-Tunisia).

Kubr, M. (1993).Conseilen Management: guide pour la profession. International Labour Organization, Genève.

Kumar, V., Maheshwari, B., \& Kumar, U. (2002). Enterprise resource planning systems adoption process: a survey of Canadian organizations. International Journal of Production Research, 40(3), 509-523. http://dx.doi.org/10.1080/00207540110092414

Lawrence, P. \&LorschJ. (1989). Adapter les structures de l'entreprise. Les Editions d'Organisation, Paris.

Le Boterf, G. (2000). La mise en place d'une démarche compétence: quelques conditions de réussite. http://www.guyleboterf-conseil.com/articles.htm.

Le boterf, G. (2002).De quel concept de compétence avons-nous besoin?http://www.guyleboterfconseil.com/articles.htm.

Le boterf, G. (2008). Repenser la compétence. Les Editions d'Organisation, Paris.

Le boterf, G. (2008).Ingénierie et évaluation des compétences. Les Editions d'Organisation, Paris. 
Lee, S.H., Shin, B. \&Lee,H. G. (2006). Knowledge Transfer in IS projects: Its Critical Role for IS Success. Proceedings of the San Diego International System Conference.

Li, S., \& Lin, B. (2006). Accessing information sharing and information quality in supply chain management. Decision support systems, 42(3), 1641-1656. http://dx.doi.org//10.1016/j.dss.2006.02.011

Liao, Y., Liao, K., Tu, Q., \&Vonderembse, M. (2011).A mechanism for external competence transfer to improve manufacturing system capabilities and market performance.International Journal of Production Economics, 132(1), 68-78. http://dx.doi.org/10.1016/j.ijpe.2011.03.007

McLachlin, R. D. (1999). Factors for consulting engagement success.Management Decision, 37(5), 394-404. http://dx.doi.org/10.1108/00251749910274162

Mezghani, K. \& Ayadi, F. (2016).Factors explaining IS managers attitudes toward Cloud Computing adoption. International Journal of Technology and Human Interaction, 12(1), In press.

Mezghani, K. (2011).Impacts des compétences des responsables d'affaires sur l'alignement stratégique des TI/SI: cas des ERP.Doctoral Dissertation (Sfax University-Tunisia).

Mezghani, K., \&Mezghani, L. (2014).Effects of Business Managers' Skills on Enterprise Resources Planning Strategic Alignment.American Journal of Business and Management, 3(1), 15-20. http://dx.doi.org/10.11634/216796061403518

Mumford, T. V., Campion, M. A., \&Morgeson, F. P. (2007). The leadership skills strataplex: Leadership skill requirements across organizational levels. The Leadership Quarterly, 18(2), 154-166. http://dx.doi.org/10.1016/j.leaqua.2007.01.005

Park, J. G., Lee, H., \& Lee, J. (2015). Applying social exchange theory in IT service relationships: exploring roles of exchange characteristics in knowledge sharing. Information Technology and Management, 16(3), 193-206. http://dx.doi.org/10.1007/s10799-015-0220-x

Poix, A. D. (2002). Culture d'entreprise et recrutement.Personnel, (431), 47-49.

Presseau, A. \& Frenay,M. (2004).Le transfert des apprentissages: comprendre pour mieuxintervenir. Les presses de l'Université Laval, Québec.

Presseau, A. (2000).Vers une utilisation des technologies de l'informationet de la communication qui favorise le développement des compétences transférables. La revue de l'AQEFLS, 22(1-2), 152-161.

Prévot, F. (2002). Le transfert inter-organisationnel de compétences: application au cas des compétenceslogistiques au Brésil, Université de la Méditerranée. http://www.strategie-aims.com/actes02/Fichiers/Pr\%C3\%A9vot.pdf.

Reed, R., \&DeFillippi, R. J. (1990).Causal ambiguity, barriers to imitation, and sustainable competitive advantage.Academy of management review, 15(1), 88-102. 
Simonin, B. L. (1999). Ambiguity and the process of knowledge transfer in strategic alliances. Strategic Management Journal, 20(7), 595-623. http://dx.doi.org/10.1002/(SICI)1097-0266(199907)20:7<595::AID-SMJ47>3.0.CO;2-5

Singla, A. R. \& Goyal, D. P. (2007). Success factors in ERP systems design implementation: an empirical investigation of the Indian industry. International Journal of Business Information Systems, 2(4), 444-464. http://dx.doi.org/10.1504/IJBIS.2007.012545

Somers, T. M. \& Nelson, K. G. (2004).A taxonomy of players and activities across the ERP project life cycle. Information \& Management, 41(3), 257-278. http://dx.doi.org/10.1016/S0378-7206(03)00023-5

Stan, V. \&Saporta, G. (2006). Une comparaison expérimentale entre les approches PLS et LISREL. In38 èmes Journées de Statistique, Clamart, France.

Stern, P. \&Tutoy,P. (1998). Le métier de consultant: principes méthodes, outils. Les Editions d'Organisation, Paris.

Strasser, A. \&Westner, M. (2015). Knowledge transfer in IS offshoring: processes, roles and success factors. Proceedings of the Pacific Asia Conference on Information Systems.

Szulanski, G. (1996). Exploring internal stickiness: Impediments to the transfer of best practice within the firm.Strategic management journal, 17(S2), 27-43. http://dx.doi.org/10.1002/smj.4250171105

Szulanski, G. (2000). The process of knowledge transfer: A diachronic analysis of stickiness. Organizational behavior and human decision processes, 82(1), 9-27. http://dx.doi.org/10.1006/obhd.2000.2884

Tenenhaus, M., Amato, S., \& Esposito Vinzi, V. (2004, June).A global goodness-of-fit index for PLS structural equation modelling.In Proceedings of the XLII SIS scientific meeting (Vol. 1, pp. 739-742). CLEUP Padova.

Tsai, W. H., Shaw, M. J., Fan, Y. W., Liu, J. Y., Lee, K. C., \& Chen, H. C. (2011). An empirical investigation of the impacts of internal/external facilitators on the project success of ERP: A structural equation model. Decision Support Systems, 50(2), 480-490. http://dx.doi.org/10.1016/j.dss.2010.11.005

Uygur, U. (2013). Determinants of causal ambiguity and difficulty of knowledge transfer within the firm. Journal of Management \&Organization, 19(06), 742-755. http://dx.doi.org/10.1017/jmo.2014.12

Vilette, M. (2003). Sociologie du conseilen management. Edition la découverte, Paris.

Vinzi, V.E., Trinchera, L. \& Amato, S. (2010). PLS Path Modeling: From Foundations to Recent Developments and Open Issues for Model Assessment and Improvement. In Vinzi, V.E., Chin, W.W., Henseler, J. \& Wang, H. (2010). Handbook of Partial Least Squares: Concepts, Methods and Applications. Springer-Verlag, Berlin. 
Wang, E. T., Klein, G., \& Jiang, J. J. (2006). ERP misfit: country of origin and organizational factors. Journal of Management Information Systems, 23(1), 263-292. http://dx.doi.org/10.2753/MIS0742-1222230109

Wernerfelt, B. (1984). A resource-based view of the firm.Strategic management journal, 5(2), 171-180. http://dx.doi.org/10.1002/smj.4250050207

Xu, Q., \& Ma, Q. (2008). Determinants of ERP implementation knowledge transfer. Information \& Management, 45(8), 528-539. http://dx.doi.org/10.1016/j.im.2008.08.004

Zander, U., \& Kogut, B. (1995). Knowledge and the speed of the transfer and imitation of organizational capabilities: An empirical test. Organization science, 6(1), 76-92. http://dx.doi.org/10.1287/orsc.6.1.76 